\title{
Effective Maintenance of Components in T700 Engine Using Backpropagation Neural Network
}

\author{
Dong-Kai Qiao, ${ }^{1}$ Yan-Zuo Chang, ${ }^{1 *}$ Tian-Syung Lan, ${ }^{2 * *}$ \\ Yung-Jen Lin, ${ }^{3}$ and Tung-Keng Yang ${ }^{3}$ \\ ${ }^{1}$ College of Mechanical and Electrical Engineering, Guangdong University of Petrochemical Technology, \\ Maoming Guangdong 525000, China \\ ${ }^{2}$ Department of Information Management, Yu Da University of Science and Technology, \\ Miaoli County 36143, Taiwan \\ ${ }^{3}$ College of Engineering, Tatung University, Taipei City 104, Taiwan
}

(Received March 31, 2021; accepted June 17, 2021)

Keywords: aircraft component, component failure, prediction of component failure, Delphi method, MAPE, backpropagation neural network

Predicting the exact time of failure for aircraft components is critical as a failure may cause a fatal accident, have a high cost, and waste a large amount of time. Accurate prediction will help reduce the occurrence of unexpected failures and ensure safe flights. Thus, we propose a model for predicting the lifetime and failure of components, which uses the modified Delphi method and a backpropagation neural network (BPNN). To select the significant factors that affect the lifetime, a questionnaire survey on experts was first carried out. As a result, 17 factors were defined, and through a second survey, the following seven factors were selected from the criteria of average scores and standard deviations: operation hours after installation, the resistance of the thermocouple assembly, and the ohm values obtained from a hydraulic machinery control unit linear displacement sensor, a power turbine speed sensor, a torque and overspeed sensor, an overspeed leakage solenoid valve, and the torque motor of the hydraulic control unit. The training data were obtained from maintenance data using various sensors of the electronic control unit (ECU) of an engine (T700) of a helicopter in Taiwan collected during 2011-2013. By using Alyuda NeuroIntelligence software, the relationship between the input and output data (predicted time to component failure) was found and used in the prediction model. The coefficients of relevance and model fitting were 0.999 and 0.997, respectively, and the average prediction accuracy of 15 data sets calculated from the mean absolute percentage error (MAPE) was $92.45 \%$. This result confirmed that the new BPNN model predicted the time of component failure effectively. The validated prediction ability of the BPNN model provides a reference for the maintenance management of various aircraft components and an effective maintenance strategy.

\footnotetext{
*Corresponding author: e-mail: changyanzuo@gmail.com **Corresponding author: e-mail: tslan888@yahoo.com.tw https://doi.org/10.18494/SAM.2021.3405
} 


\section{Introduction}

Aircraft play an important role in transportation as well as national defense. Unexpected failures in parts and components during flight significantly affect flight safety and require immediate maintenance. The authority overseeing Taiwan's aviation maintenance has analyzed the causes of failure in the control units and modules of aircraft and found that the electronic control units (ECUs) of aircraft most frequently have problems. The main function of the ECU is to process signals from the sensors of the altimeter, power turbine tachometer, torque and overspeed controller, hydraulic mechanical control unit, and various temperature control units. ${ }^{(1)}$ The ECU also receives data on rotor speed, collective rod angle, and changes in rotor load from other sensors. The data are processed for precise control by outputting signals to control the power turbine speed, torque, exhaust temperature, fuel flow control, engine load distribution, torque limitation, and so forth.

The results of the analysis of the causes of component failures show that the main causes are collisions with foreign objects and the misalignment of electrical connectors during reassembly. The causes of failure and prevention measures are shown in Table 1. The damaged components must be replaced without effective technical instruction from the manufacturer. However, this requires time and money along with appropriate stock management. Therefore, an effective plan and strategy for the maintenance are necessary to save time and cost as well as to enhance operational efficiency.

To establish a model for predicting the failure and service life of components, we adopted the Delphi model and a backpropagation neural network (BPNN). Since RAND Corporation developed the Delphi method, it has been widely used in research on the environment, industry, health, transportation, education, and social sciences, and in policy evaluation by government and academic institutions. ${ }^{(2)}$ The Delphi method is a decision-making model that provides quality information for exploratory and controversial research, and the results obtained are valuable. ${ }^{(3)}$ The method uses a series of questionnaires with controlled feedback that is obtained from experts' opinions and a consensus when there is insufficient information. Experts are asked to provide professional knowledge, experience, and opinions to achieve a consensus on a specific issue. As a modification of the Delphi method, in 1995, Murry and Hommons proposed a two-step survey: an open questionnaire survey (modified Delphi method) followed by a structured questionnaire. The modified Delphi method saves time by avoiding speculation and

Table 1

Causes and measures for preventing failures of the ECU.

\begin{tabular}{lccc}
\hline Damage & Fault location & Causes & Defensive action \\
\hline $\begin{array}{l}\text { Internal } \\
\text { damage }\end{array}$ & $\begin{array}{c}\text { Circuit cards, transistors, } \\
\text { resistors of each module }\end{array}$ & $\begin{array}{c}\text { Poor engine operation function } \\
\text { or abnormal display of related } \\
\text { instruments during flight }\end{array}$ & $\begin{array}{c}\text { Quantitative analysis and research } \\
\text { to improve equipment reliability }\end{array}$ \\
\hline $\begin{array}{l}\text { External } \\
\text { damage }\end{array}$ & $\begin{array}{c}\text { Electrical connectors, } \\
\text { screws, shells }\end{array}$ & $\begin{array}{c}\text { Collision or misalignment of } \\
\text { electrical connectors during } \\
\text { disassembly and assembly }\end{array}$ & $\begin{array}{c}\text { Training of maintenance personnel, } \\
\text { implementation of inspection and } \\
\text { maintenance mechanisms }\end{array}$ \\
\hline
\end{tabular}


allows participating experts to focus on issues and increase the response rate. ${ }^{(4)}$ The data from the Delphi method has been processed by using a BPNN.

As neural networks have sufficient capability for data classification, prediction, noise filtering, signal analysis, control, and so forth, they have a wide range of applications. Neural networks are used for solving various problems such as turbo engine diagnosis, ${ }^{(5)}$ storm prediction, stock price forecasting, ${ }^{(6)}$ power demand, wafer probing, microchip production, ${ }^{(7)}$ component demand, ${ }^{(8)}$ and heat-mechanical effect processing. ${ }^{(9)}$

The BPNN was proposed and modified by many researchers, ${ }^{(10,11)}$ and is now widely used. The basic principle is to use the gradient descent method to minimize the error function and then to derive the delta rule. The process of BPNN is divided into forward and reverse transfer, which reduces errors in obtaining desired learning results. The functions are regarded as powerful and extensive for deriving results from a complex and two-layered survey system in the Delphi method. In this study, factors affecting the time of failure of an ECU are defined by the Delphi method by using expert questionnaire surveys.

The aim of our research is to establish a model for predicting the failure and service life of the components of helicopters to enable their repair and replacement at a suitable time. An appropriate maintenance plan and strategy will prevent the occurrence of an unexpected failure during flight and reduce the frequency of unexpected maintenance, thereby increasing the operation time of aircraft. The newly proposed accurate prediction model for the failure time of components will enhance flight safety as well as operational efficiency.

\section{Methods}

\section{$2.1 \quad$ T700 engine}

To establish an appropriate prediction model, the ECU of the engine of a T700 helicopter developed and manufactured by BAE Systems Controls Inc. was used. The ECU is shown in Fig. 1.

According to the statistics of maintenance records from 2006 to 2013, a total of 87 units had failures, among which 45 units suffered from internal module damage and 24 units suffered from damage to external components. The other units were sent to the manufacturer. Detailed information on the damage is shown in Table 2.

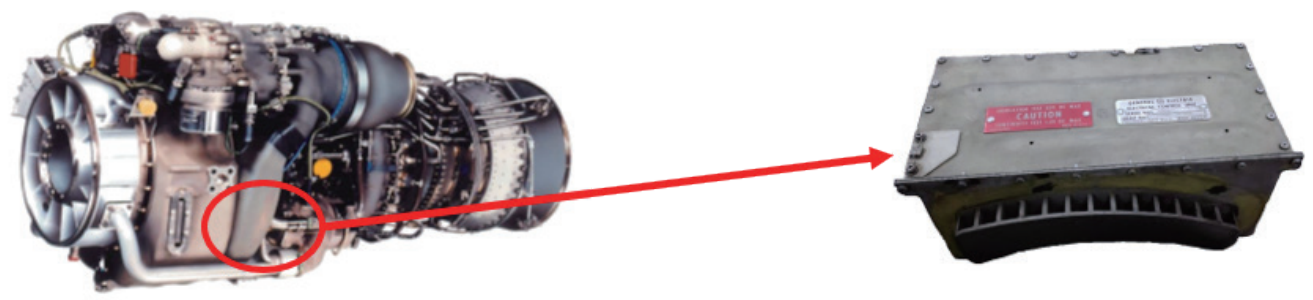

Fig. 1. (Color online) T700 engine (left) and ECU (right). 
Table 2

Damage to ECUs and their frequencies of occurrence.

\begin{tabular}{llccc}
\hline Damage & Damaged component & Occurrence & Total & Proportion (\%) \\
& Power shaft speed signal module & 13 & & \\
& Tail temperature signal control and compensation module & 12 & & \\
Internal & Torque signal module & 4 & \multirow{2}{*}{52} \\
damage & Linear displacement sensor square wave generator module & 1 & & \\
& Power shaft overspeed module & 8 & & \\
& Sudden deceleration compensation module & 7 & & \multirow{2}{*}{27} \\
External & Electrical connector & 10 & \multirow{2}{*}{24} & 21 \\
damage & Others (substrate, heat shield, cover) & 14 & & \\
\hline Others & Test without damage & 18 & 18 & 21
\end{tabular}

\subsection{Modified Delphi method}

RAND Corporation developed the Delphi method, which uses a series of questionnaires with controlled feedback information. The main purpose of the Delphi method is to use experts' opinions and develop a strategic plan. The Delphi method is mainly used when information is insufficient or unknown. Experts are asked to contribute their professional knowledge, experience, and opinions to achieve a consensus on a specific issue. The method has the following properties.

(1) The depth and continuity of a group's consideration of future trends are expressed better than those of individuals.

(2) An objective consensus is found by employing anonymous and written opinions and discussions among experts.

(3) The interviewed experts are generally well recognized in their fields for delivering representative opinions.

(4) At least two rounds of opinion surveys are carried out to quantify and analyze the collected opinions.

The modified Delphi method was used for this study with 12 senior experts with more than 10 years of experience on the T700, as certified by the manufacturer, and various positions and educational backgrounds (Table 3). The purpose of the first questionnaire was to select the important factors that affect the maintenance of the ECU of the T700. As a result, 17 key factors were selected, as shown in Table 4.

Then, the experts were asked to rate the importance of the items with the following Likert scale: "very important" (5), "important" (4), "normal" (3), "not important" (2), and "very unimportant" (1). ${ }^{(12)}$ To select representative factors, a consistency index was calculated. For the index, the average and standard deviation of the scores were calculated for each item. The standard deviation was used to check whether the scores were consistent. Items with an average of 4.5 points or more were classified as "most important", while those with an average of 4.0 to 4.5 were classified as "important", and those with an average of 3.5 to 4.0 were classified as "reference" items. ${ }^{(13)}$ Standard deviation is a measure of the degree to which a set of values 
Table 3

Invited experts for the questionnaire survey.

\begin{tabular}{|c|c|c|c|c|}
\hline Number & Working department & Position & $\begin{array}{c}\text { Experience } \\
\text { (years) }\end{array}$ & Education \\
\hline 1 & \multirow{3}{*}{ Technology R\&D Department } & Engineer & 25 & Ph.D. \\
\hline 2 & & Engineer & 16 & Ph.D. \\
\hline 3 & & Engineer & 10 & Master's degree \\
\hline 4 & \multirow{3}{*}{ Engineering Department } & Engineer & 16 & Ph.D. \\
\hline 5 & & Inspector & 18 & Master's degree \\
\hline 6 & & Foreman & 15 & Bachelor's degree \\
\hline 7 & \multirow{3}{*}{ Professional Maintenance Department } & Inspector & 17 & Master's degree \\
\hline 8 & & Foreman & 13 & Master's degree \\
\hline 9 & & Technician & 11 & Bachelor's degree \\
\hline 10 & \multirow{3}{*}{ Station Maintenance Department } & Inspector & 16 & Master's degree \\
\hline 11 & & Foreman & 14 & Bachelor's degree \\
\hline 12 & & Technician & 10 & Diploma \\
\hline
\end{tabular}

Table 4

Counts of the factors chosen by experts in the questionnaire survey.

\begin{tabular}{ccc}
\hline No. & Factor & Count \\
\hline 1 & Times of disassembly & 3 \\
\hline 2 & Maintenance period & 2 \\
\hline 3 & Thermocouple assembly & 10 \\
\hline 4 & Operating environment humidity & 2 \\
\hline 5 & Operating environment temperature & 3 \\
\hline 6 & Storage environment humidity & 4 \\
\hline 7 & Storage temperature & 5 \\
\hline 8 & Operation hours after installation & 12 \\
\hline 9 & Improper operations & 4 \\
\hline 10 & Hours of use after renovation & 6 \\
\hline 11 & Torque and overspeed sensor & 7 \\
\hline 12 & Overspeed leakage solenoid valve & 10 \\
\hline 13 & Power turbine speed sensor & 10 \\
\hline 15 & Tail temperature signal control and compensation module & 11 \\
\hline 16 & Hydraulic-mechanical control unit torque motor & 7 \\
\hline 17 & Hydro-mechanical control unit linear variable displacement sensor & 12 \\
\hline
\end{tabular}

diverge from the average. ${ }^{(14)}$ A standard deviation of less than 1 was considered to mean that the opinions of experts converged and were representative. ${ }^{(15)}$

\subsection{BPNN}

NeuroIntelligence software by Alyuda Research LLC was used as it is one of the best prediction software packages. Its main application functions are prediction, classification, function calculation, and data anomaly detection. The data of the ECU of the Taiwan Aviation Maintenance Department obtained from 2011 to 2013 was used to test the BPNN model. The data included 80 sets of parameters of 50 ECUs with different serial numbers. 


\section{Results}

\subsection{Important factors for maintenance of ECU of T700}

The results of the second expert questionnaire are shown in Table 5. The average score and standard deviation of each factor were calculated. The factors with average $>4$ and standard deviation $<1$ were regarded as important and consistent factors. ${ }^{(16)}$

The selected factors are as follows: operation hours after installation, thermocouple assembly, hydraulic machinery control unit linear displacement sensor, power turbine speed sensor, torque and overspeed sensor, overspeed leakage solenoid valve, and hydraulic mechanical control unit torque motor. These were used as the main parameters and input values for the BPNN modeling. The data for the selected factors are shown in Appendix I.

\subsection{Prediction model and training}

Selected parameters of the seven factors were used to establish a prediction model using Alyuda NeuroIntelligence software. The sensitivity of the prediction data was obtained to understand how the model changed with changes in each parameter.

The results of the learning model obtained through training were as follows:

(1) The software automatically connects the input, hidden, and output layer for the best matching. One hidden layer has 12 neurons. The learning rate of 0.2 and 2000 epochs yielded the best training result. Figure 2 shows that stable convergence is reached under these conditions.

Table 5

Results of questionnaires showing expert scores.

\begin{tabular}{|c|c|c|c|c|c|c|c|c|c|c|c|c|c|}
\hline Factors & 1 & 2 & 3 & 4 & 5 & 6 & 7 & 8 & 9 & 10 & Total & Average & S.D. \\
\hline Operation hours after installation $^{*}$ & 5 & 4 & 4 & 5 & 5 & 5 & 4 & 5 & 4 & 5 & 46 & 4.6 & 0.52 \\
\hline Thermocouple assembly $^{*}$ & 4 & 5 & 5 & 4 & 4 & 4 & 4 & 5 & 5 & 4 & 44 & 4.4 & 0.52 \\
\hline Torque and overspeed sensor ${ }^{*}$ & 4 & 4 & 5 & 4 & 4 & 5 & 5 & 4 & 5 & 4 & 44 & 4.4 & 0.52 \\
\hline Overspeed leakage solenoid valve $^{*}$ & 5 & 4 & 4 & 5 & 5 & 4 & 5 & 4 & 4 & 4 & 44 & 4.4 & 0.52 \\
\hline Power turbine speed sensor ${ }^{*}$ & 5 & 4 & 4 & 5 & 5 & 4 & 4 & 5 & 4 & 4 & 44 & 4.4 & 0.52 \\
\hline $\begin{array}{l}\text { Torque motor of hydraulic mechanical control } \\
\text { unit }^{*}\end{array}$ & 5 & 5 & 4 & 4 & 5 & 4 & 4 & 5 & 4 & 5 & 45 & 4.5 & 0.53 \\
\hline $\begin{array}{l}\text { Linear displacement sensor of hydro-mechanical } \\
\text { control unit }{ }^{*}\end{array}$ & 5 & 5 & 4 & 4 & 5 & 4 & 4 & 5 & 4 & 5 & 45 & 4.5 & 0.53 \\
\hline $\begin{array}{l}\text { Tail temperature signal control and compensation } \\
\text { module }\end{array}$ & 3 & 3 & 2 & 3 & 3 & 2 & 3 & 3 & 2 & 3 & 27 & 2.7 & 0.48 \\
\hline Improper operations & 2 & 3 & 2 & 2 & 3 & 3 & 2 & 3 & 2 & 3 & 25 & 2.5 & 0.53 \\
\hline Times of disassembly & 3 & 3 & 2 & 3 & 2 & 3 & 2 & 3 & 1 & 2 & 24 & 2.4 & 0.70 \\
\hline Sudden deceleration compensation module & 3 & 4 & 2 & 3 & 2 & 2 & 2 & 3 & 2 & 3 & 26 & 2.6 & 0.70 \\
\hline Maintenance period & 3 & 4 & 2 & 2 & 2 & 2 & 2 & 3 & 2 & 3 & 25 & 2.5 & 0.71 \\
\hline Operating environment humidity & 3 & 4 & 2 & 2 & 2 & 2 & 2 & 3 & 2 & 3 & 25 & 2.5 & 0.71 \\
\hline Operating environment temperature & 2 & 3 & 1 & 2 & 2 & 2 & 2 & 3 & 1 & 2 & 20 & 2 & 0.67 \\
\hline Hours of use after renovation & 2 & 2 & 1 & 1 & 1 & 1 & 1 & 2 & 1 & 2 & 14 & 1.4 & 0.52 \\
\hline Storage temperature & 3 & 3 & 2 & 2 & 2 & 2 & 2 & 3 & 2 & 3 & 24 & 2.4 & 0.52 \\
\hline Storage environment humidity & 3 & 3 & 2 & 2 & 2 & 3 & 4 & 4 & 3 & 4 & 30 & 3 & 0.82 \\
\hline
\end{tabular}

S.D.: standard deviation, ${ }^{*}$ : factors selected for further investigation

10 questionnaires were returned from 12 distributed ones. 
(2) The software calculates the relevance and matching of the model. A value of relevance close to 1 represents a high degree of positive correlation and high prediction accuracy. A value of matching close to 1 signifies the appropriateness of the model. This is because the high explanatory ability of an independent variable corresponds to a good fit of the model. The training results of the relevance and matching of the model are shown in Table 6.

(3) The training reduced the error between the target value (red line) and the output value (blue line) (Fig. 3) and obtained a better prediction. The learning result of the comparison between the target value and the output value is shown in Fig. 3.

(4) After inputting the parameters of the seven factors, the software calculated the predicted hours to failure after fault detection as shown in Fig. 4. According to the example, the failure was predicted to occur $193 \mathrm{~h}$ after fault detection. This means that the failure would have occurred $2193 \mathrm{~h}$ after the installation of the ECU.

\subsection{Forecast accuracy}

The mean absolute percentage error (MAPE) is an indicator of the quality of a prediction model. MAPE is a relative value and is not affected by the unit and size of the measured and estimated values. MAPE of less than $10 \%$ implies highly accurate prediction, while those of $10-20 \%, 20-50 \%$, and larger than $50 \%$ imply good, reasonable, and inaccurate prediction, respectively. ${ }^{(17)}$

We used 15 sets of real failure data of the ECU in 2014 to obtain MAPEs. By importing the data into the input layer of the software, the time (in $\mathrm{h}$ ) to component failure after fault detection

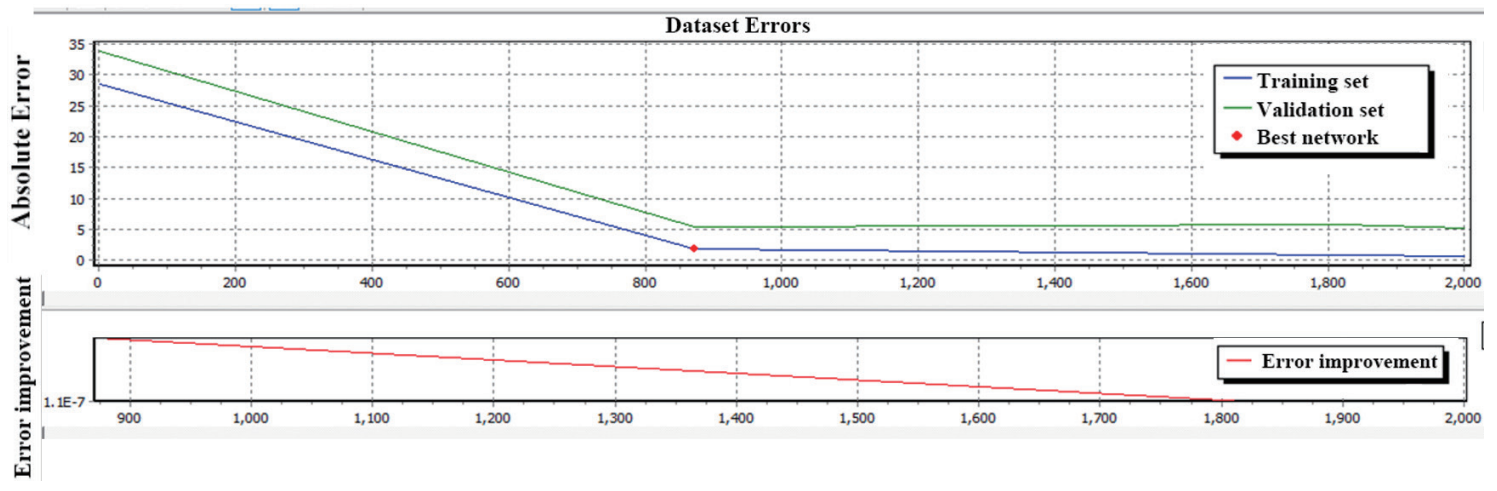

Fig. 2. (Color online) Diagram showing best training mode.

Table 6

Relevance and matching values of the prediction model.

\begin{tabular}{lcccc}
\hline Statistic & Target value & Output value & Absolute error & Relative error \\
\hline Average & 150.828571 & 150.82453 & 0.763588 & 0.005516 \\
Standard deviation & 32.392667 & 31.872821 & 1.224086 & 0.009735 \\
Maximum value & 85 & 87.609564 & 0.000307 & 0.000002 \\
Minimum value & 198 & 193.814397 & 6.530368 & 0.056260 \\
\hline \multicolumn{5}{c}{ Relevance: 0.999} \\
& Mode fit: 0.997 & \\
\end{tabular}




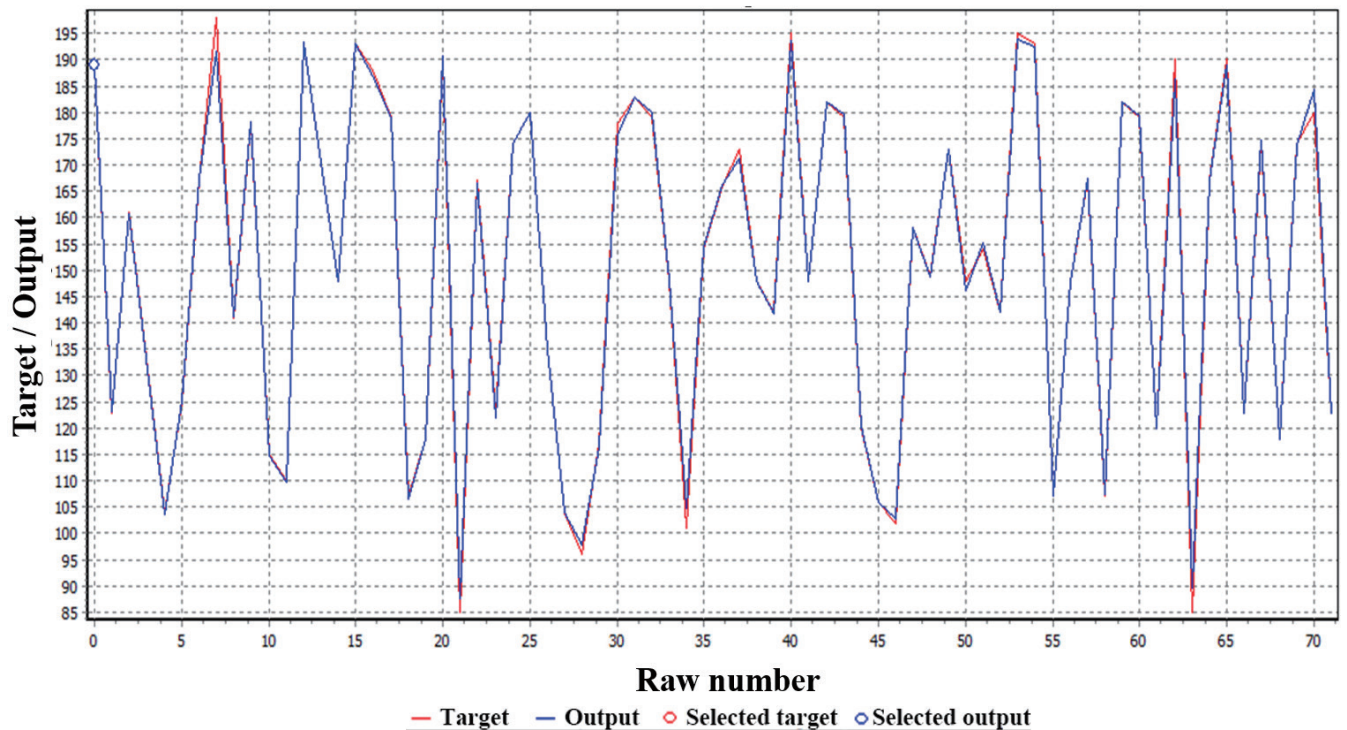

Fig. 3. (Color online) Comparison of target value and output value.

\begin{tabular}{|c|c|c|c|c|c|c|c|}
\hline \multicolumn{8}{|c|}{ Manual Query } \\
\hline \multicolumn{8}{|c|}{ dits } \\
\hline $\begin{array}{c}\text { Operation } \\
\text { hours after } \\
\text { installation } \\
\text { (hour) }\end{array}$ & $\begin{array}{l}\text { Thermocouple } \\
\text { Assembly }(\Omega)\end{array}$ & $\begin{array}{c}\text { Hydraulic } \\
\text { machinery } \\
\text { control unit } \\
\text { Linear } \\
\text { displacement } \\
\text { sensor }(\Omega) \\
\end{array}$ & $\begin{array}{c}\text { Power } \\
\text { turbine } \\
\text { speed } \\
\text { sensor } \\
(\Omega)\end{array}$ & $\begin{array}{c}\text { Torque } \\
\text { and } \\
\text { overspeed } \\
\text { sensor }(\Omega)\end{array}$ & $\begin{array}{c}\text { Overspeed } \\
\text { leakage } \\
\text { solenoid } \\
\text { valve }(\Omega)\end{array}$ & $\begin{array}{l}\text { Hydraulic } \\
\text { mechanical } \\
\text { control unit } \\
\text { torque } \\
\text { motor }(\Omega)\end{array}$ & \\
\hline 2000 & 4 & 22 & 18 & 17 & 23 & 84 & \\
\hline $\max : 2750$ & $\max : 4.2$ & $\max : 22.4$ & $\max : 18.2$ & $\max : 17.7$ & $\max : 23.6$ & $\max : 84.1$ & \\
\hline $\min : 780$ & $\min : 2.3$ & $\min : 17.8$ & $\min : 15.6$ & $\min : 15.5$ & $\min : 20.5$ & $\min : 67.7$ & \\
\hline \multicolumn{8}{|c|}{ Results Table } \\
\hline \multicolumn{8}{|c|}{ 日炨|X } \\
\hline $\begin{array}{c}\text { Operation } \\
\text { hours after } \\
\text { installation } \\
\text { (hour) }\end{array}$ & $\begin{array}{l}\text { Thermocouple } \\
\text { Assembly }(\Omega)\end{array}$ & $\begin{array}{c}\text { Hydraulic } \\
\text { machinery } \\
\text { control unit } \\
\text { Linear } \\
\text { displacement } \\
\text { sensor }(\Omega) \\
\end{array}$ & $\begin{array}{c}\text { Power } \\
\text { turbine } \\
\text { speed } \\
\text { sensor } \\
(\Omega)\end{array}$ & $\begin{array}{c}\text { Torque } \\
\text { and } \\
\text { overspeed } \\
\text { sensor }(\Omega)\end{array}$ & $\begin{array}{c}\text { Overspeed } \\
\text { leakage } \\
\text { solenoid } \\
\text { valve }(\Omega)\end{array}$ & $\begin{array}{l}\text { Hydraulic } \\
\text { mechanical } \\
\text { control unit } \\
\text { torque } \\
\operatorname{motor}(\Omega)\end{array}$ & $\begin{array}{l}\text { Failure after fault } \\
\text { detection (hour) }\end{array}$ \\
\hline 2000 & 4 & 22 & 18 & 17 & 23 & 84 & 193.03433 \\
\hline
\end{tabular}

Fig. 4. (Color online) Schematic diagram of the learning model prediction.

was obtained by the output layer and compared with the 15 sets of data. MAPE was $7.55 \%$ with the highest error rate of $9.47 \%$. The result shows that the prediction of the number of hours to component failure after fault detection by the BPNN model was highly accurate (Table 7).

\subsection{Important key factors for prediction of failure time}

The prediction model verified which factors directly affected the failure time. The verification process was as follows.

(1) Operation hours after installation of $2700,2500,2000,1500$, and $1000 \mathrm{~h}$ were input to the model with the other six factors constant. The predicted times to failure after fault detection 
Table 7

Percentage errors and MAPEs of input and output layers and real data.

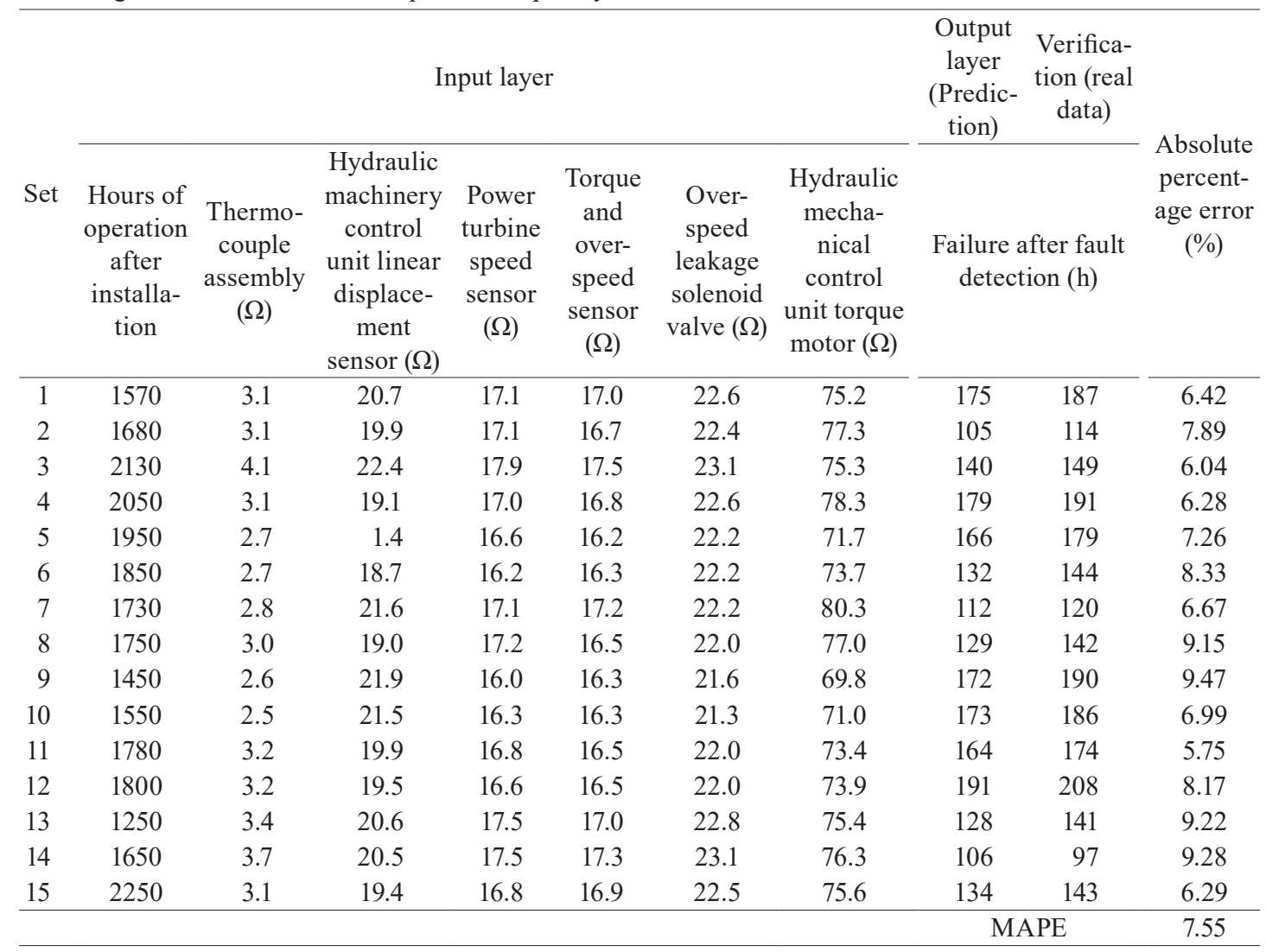

\begin{tabular}{|c|c|c|c|c|c|c|c|}
\hline \multicolumn{8}{|c|}{ Manual Query } \\
\hline \multicolumn{8}{|c|}{ d } \\
\hline $\begin{array}{c}\text { Operation } \\
\text { hours after } \\
\text { installation } \\
\text { (hour) }\end{array}$ & $\begin{array}{l}\text { Thermocouple } \\
\text { Assembly }(\Omega)\end{array}$ & $\begin{array}{c}\text { Hydraulic } \\
\text { machinery } \\
\text { control unit } \\
\text { Linear } \\
\text { displacement } \\
\text { sensor }(\Omega) \\
\end{array}$ & $\begin{array}{c}\text { Power } \\
\text { turbine } \\
\text { speed } \\
\text { sensor } \\
(\Omega) \\
\end{array}$ & $\begin{array}{c}\text { Torque } \\
\text { and } \\
\text { overspeed } \\
\text { sensor }(\Omega)\end{array}$ & $\begin{array}{l}\text { Overspeed } \\
\text { leakage } \\
\text { solenoid } \\
\text { valve }(\Omega)\end{array}$ & $\begin{array}{c}\text { Hydraulic } \\
\text { mechanical } \\
\text { control unit } \\
\text { torque } \\
\text { motor }(\Omega)\end{array}$ & \\
\hline 1000 & 4 & 22 & 18 & 17 & 23 & 84 & \\
\hline $\max : 2750$ & $\max : 4.2$ & $\max : 22.4$ & $\max : 18.2$ & $\max : 17.7$ & $\max : 23.6$ & $\max : 84.1$ & \\
\hline $\min : 780$ & $\min : 2.3$ & $\min : 17.8$ & $\min : 15.6$ & min: 15.5 & $\min : 20.5$ & $\min : 67.7$ & \\
\hline \multicolumn{8}{|c|}{ Results Table } \\
\hline \multicolumn{8}{|c|}{ 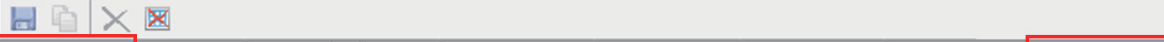 } \\
\hline $\begin{array}{c}\text { Operation } \\
\text { hours after } \\
\text { installation } \\
\text { (hour) }\end{array}$ & \begin{tabular}{|l|} 
Thermocouple \\
Assembly $(\Omega)$
\end{tabular} & $\begin{array}{c}\text { Hydraulic } \\
\text { machinery } \\
\text { control unit } \\
\text { Linear } \\
\text { displacement } \\
\text { sensor }(\Omega)\end{array}$ & $\begin{array}{c}\text { Power } \\
\text { turbine } \\
\text { speed } \\
\text { sensor } \\
(\Omega) \\
\end{array}$ & $\begin{array}{c}\text { Torque } \\
\text { and } \\
\text { overspeed } \\
\text { sensor }(\Omega)\end{array}$ & $\begin{array}{c}\text { Overspeed } \\
\text { leakage } \\
\text { solenoid } \\
\text { valve }(\Omega)\end{array}$ & $\begin{array}{c}\text { Hydraulic } \\
\text { mechanical } \\
\text { control unit } \\
\text { torque } \\
\text { motor }(\Omega)\end{array}$ & $\begin{array}{l}\text { Failure after fault } \\
\text { detection (hour) }\end{array}$ \\
\hline 2700 & 7 & 22 & 18 & 17 & 23 & 84 & 173.199417 \\
\hline 2500 & 4 & 22 & 18 & 17 & 23 & 84 & 192.762944 \\
\hline 2000 & 4 & 22 & 18 & 17 & 23 & 84 & 193.034542 \\
\hline 1500 & 4 & 22 & 18 & 17 & 23 & 84 & 115.77334 \\
\hline 1000 & 4 & 22 & 18 & 17 & 23 & 84 & 178.559795 \\
\hline
\end{tabular}

Fig. 5. (Color online) Result of model showing the relation between hours of operation after installation and the predicted time of component failure.

were $173,192,193,115$, and $178 \mathrm{~h}$, respectively. This showed that the operation time after the installation was not directly related to the prediction (Fig. 5). 
(2) The times of thermocouple assembly of 4.2, 4.1, 4, 3, and 2.5 were input with the other six factors constant. The predicted times were 191, 192, 193, 185, and $164 \mathrm{~h}$, respectively, which implied that the time of thermocouple assembly was related to the prediction (Fig. 6).

(3) The ohm values of the linear displacement sensor of the hydraulic machinery control unit were input as $22.4,22.2,22,20$, and $18 \Omega$ with the other factors constant. The predicted times were 195, 194, 193, 148, and $147 \mathrm{~h}$, respectively, which shows that the ohm value of the linear displacement sensor affected the prediction significantly (Fig. 7).

(4) The ohm values of the power turbine speed sensor of 18.2, 18.1, 18, 17, and $16 \Omega$ with the other factors constant were used in the calculation, and the predicted times were 195, 194,

\begin{tabular}{|c|c|c|c|c|c|c|c|}
\hline \multicolumn{8}{|c|}{ Manual Query } \\
\hline \multicolumn{8}{|c|}{ d $\mid$\begin{tabular}{|l|l|}
$\mathbf{3}$ & $\pm / 2$ \\
\end{tabular}} \\
\hline $\begin{array}{l}\text { Operation } \\
\text { hours after } \\
\text { installation } \\
\text { (hour) }\end{array}$ & $\begin{array}{l}\text { Thermocouple } \\
\text { Assembly }(\Omega)\end{array}$ & $\begin{array}{c}\text { Hydraulic } \\
\text { machinery } \\
\text { control unit } \\
\text { Linear } \\
\text { displacement } \\
\text { sensor }(\Omega) \\
\end{array}$ & $\begin{array}{c}\text { Power } \\
\text { turbine } \\
\text { speed } \\
\text { sensor } \\
(\Omega) \\
\end{array}$ & $\begin{array}{l}\text { Torque } \\
\text { and } \\
\text { overspeed } \\
\text { sensor }(\Omega)\end{array}$ & $\begin{array}{l}\text { Overspeed } \\
\text { leakage } \\
\text { solenoid } \\
\text { valve }(\Omega)\end{array}$ & $\begin{array}{c}\text { Hydraulic } \\
\text { mechanical } \\
\text { control unit } \\
\text { torque } \\
\text { motor }(\Omega) \\
\end{array}$ & \\
\hline 2000 & 2.5 & 22 & 18 & 17 & 23 & 84 & \\
\hline $\max : 2750$ & $\max : 4.2$ & $\max : 22.4$ & $\max : 18.2$ & $\max : 17.7$ & $\max : 23.6$ & $\max : 84.1$ & \\
\hline $\min : 780$ & $\min : 2.3$ & $\min : 17.8$ & $\min : 15.6$ & $\min : \mathbf{1 5 . 5}$ & $\min : 20.5$ & $\min : 67.7$ & \\
\hline \multicolumn{8}{|c|}{ Results Table } \\
\hline \multicolumn{8}{|c|}{ 回宙|X国 } \\
\hline $\begin{array}{l}\text { Operation } \\
\text { hours after } \\
\text { installation } \\
\text { (hour) }\end{array}$ & $\begin{array}{l}\text { Thermocouple } \\
\text { Assembly }(\Omega)\end{array}$ & $\begin{array}{c}\text { Hydraulic } \\
\text { machinery } \\
\text { control unit } \\
\text { Linear } \\
\text { displacement } \\
\text { sensor(o) }\end{array}$ & $\begin{array}{c}\text { Power } \\
\text { turbine } \\
\text { speed } \\
\text { sensor } \\
(\Omega) \\
\end{array}$ & $\begin{array}{c}\text { Torque } \\
\text { and } \\
\text { overspeed } \\
\text { sensor }(\Omega)\end{array}$ & $\begin{array}{l}\text { Overspeed } \\
\text { leakage } \\
\text { solenoid } \\
\text { valve }(\Omega)\end{array}$ & $\begin{array}{c}\text { Hydraulic } \\
\text { mechanical } \\
\text { control unit } \\
\text { torque } \\
\text { motor }(\Omega) \\
\end{array}$ & $\begin{array}{c}\text { Failure after fault } \\
\text { detection (hour) }\end{array}$ \\
\hline 2000 & 4.2 & 22 & 18 & 17 & 23 & 84 & 191.608836 \\
\hline 2000 & 4.1 & 22 & 18 & 17 & 23 & 84 & 192.182267 \\
\hline 2000 & 4 & 22 & 18 & 17 & 23 & 84 & 193.034542 \\
\hline 2000 & 3 & 22 & 18 & 17 & 23 & 84 & 185.87039 \\
\hline 2000 & 2.5 & 22 & 18 & 17 & 23 & 84 & 164.489277 \\
\hline
\end{tabular}

Fig. 6. (Color online) Result of model showing the relation between time of thermocouple assembly and predicted time of component failure.

\begin{tabular}{|c|c|c|c|c|c|c|c|}
\hline \multicolumn{8}{|c|}{ Manual Query } \\
\hline \multicolumn{8}{|c|}{ 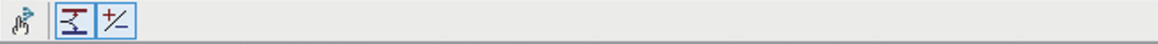 } \\
\hline $\begin{array}{c}\text { Operation } \\
\text { hours after } \\
\text { installation } \\
\text { (hour) }\end{array}$ & $\begin{array}{l}\text { Thermocouple } \\
\text { Assembly ( } \Omega)\end{array}$ & $\begin{array}{c}\text { Hydraulic } \\
\text { machinery } \\
\text { control unit } \\
\text { Linear } \\
\text { displacement } \\
\text { sensor }(\Omega) \\
\end{array}$ & $\begin{array}{c}\text { Power } \\
\text { turbine } \\
\text { speed } \\
\text { sensor } \\
(\Omega) \\
\end{array}$ & $\begin{array}{c}\text { Torque } \\
\text { and } \\
\text { overspeed } \\
\text { sensor }(\Omega)\end{array}$ & $\begin{array}{l}\text { Overspeed } \\
\text { leakage } \\
\text { solenoid } \\
\text { valve }(\Omega)\end{array}$ & $\begin{array}{c}\text { Hydraulic } \\
\text { mechanical } \\
\text { control unit } \\
\text { torque } \\
\text { motor }(\Omega) \\
\end{array}$ & \\
\hline 2000 & 4 & 18 & 18 & 17 & 23 & 84 & \\
\hline $\max : \mathbf{2 7 5 0}$ & $\max : 4.2$ & $\max : 22.4$ & $\max : \mathbf{1 8 . 2}$ & $\max : 17.7$ & $\max : 23.6$ & $\max : 84.1$ & \\
\hline $\min : 780$ & $\min : 2.3$ & $\min : 17.8$ & min: $\mathbf{1 5 . 6}$ & $\min : 15.5$ & min: 20.5 & $\min : 67.7$ & \\
\hline \multicolumn{8}{|c|}{ Results Table } \\
\hline \multicolumn{8}{|c|}{ 回缁 $\times$ 国 } \\
\hline $\begin{array}{l}\text { Operation } \\
\text { hours after } \\
\text { installation } \\
\text { (hour) }\end{array}$ & $\begin{array}{l}\text { Thermocouple } \\
\text { Assembly }(\Omega)\end{array}$ & $\begin{array}{c}\text { Hydraulic } \\
\text { machinery } \\
\text { control unit } \\
\text { Linear } \\
\text { displacement } \\
\text { sensor }(\Omega) \\
\end{array}$ & $\begin{array}{c}\text { Power } \\
\text { turbine } \\
\text { speed } \\
\text { sensor } \\
(\Omega)\end{array}$ & $\begin{array}{c}\text { Torque } \\
\text { and } \\
\text { overspeed } \\
\text { sensor }(\Omega)\end{array}$ & $\begin{array}{c}\text { Overspeed } \\
\text { leakage } \\
\text { solenoid } \\
\text { valve }(\Omega)\end{array}$ & $\begin{array}{l}\text { Hydraulic } \\
\text { mechanical } \\
\text { control unit } \\
\text { torque } \\
\text { motor }(\Omega)\end{array}$ & $\begin{array}{c}\text { Failure after fault } \\
\text { detection (hour) }\end{array}$ \\
\hline 2000 & 4 & 22.4 & 18 & 17 & 23 & 84 & 195.603037 \\
\hline 2000 & 4 & 22.2 & 18 & 17 & 23 & 84 & 194.595594 \\
\hline 2000 & 4 & 22 & 18 & 17 & 23 & 84 & 193.034542 \\
\hline 2000 & 4 & 20 & 18 & 17 & 23 & 84 & 148.381949 \\
\hline 2000 & 4 & 18 & 18 & 17 & 23 & 84 & 147347174 \\
\hline
\end{tabular}

Fig. 7. (Color online) Result of model showing the relation between the ohm value of the linear displacement sensor of the hydraulic machinery control unit and the predicted time of component failure. 
193, 193, and $195 \mathrm{~h}$, respectively. There was no direct correlation found between the ohm value of the power turbine speed sensor and the prediction (Fig. 8).

(5) The ohm values of the torque and overspeed sensor were input as 17.6, 17.3, 17, 16, and $15.5 \Omega$ with the other factors constant. The predicted times to failure were 193, 191, 193, 173, and $167 \mathrm{~h}$, respectively, which showed that the ohm value of the torque and overspeed sensor was not directly related to the prediction (Fig. 9).

(6) The ohm values of the overspeed leakage solenoid valve of 23.6, 23.3, 23, 22, and $21 \Omega$ were input with the other factors constant. The predicted times to failure were 159, 182, 193, 195, and $177 \mathrm{~h}$, respectively, showing that the ohm value of the valve did not affect the predicted time (Fig. 10).

\begin{tabular}{|c|c|c|c|c|c|c|c|}
\hline \multicolumn{8}{|c|}{ Manual Query } \\
\hline \multicolumn{8}{|c|}{ d } \\
\hline $\begin{array}{c}\text { Operation } \\
\text { hours after } \\
\text { installation } \\
\text { (hour) }\end{array}$ & $\begin{array}{l}\text { Thermocouple } \\
\text { Assembly }(\Omega)\end{array}$ & $\begin{array}{c}\text { Hydraulic } \\
\text { machinery } \\
\text { control unit } \\
\text { Linear } \\
\text { displacement } \\
\text { sensor }(\Omega) \\
\end{array}$ & $\begin{array}{c}\text { Power } \\
\text { turbine } \\
\text { speed } \\
\text { sensor } \\
(\Omega) \\
\end{array}$ & $\begin{array}{l}\text { Torque } \\
\text { and } \\
\text { overspeed } \\
\text { sensor }(\Omega)\end{array}$ & $\begin{array}{l}\text { Overspeed } \\
\text { leakage } \\
\text { solenoid } \\
\text { valve }(\Omega)\end{array}$ & $\begin{array}{c}\text { Hydraulic } \\
\text { mechanical } \\
\text { control unit } \\
\text { torque } \\
\text { motor }(\Omega)\end{array}$ & \\
\hline 2000 & 4 & 22 & 16 & 17 & 23 & 84 & \\
\hline $\max : 2750$ & $\max : 4.2$ & $\max : 22.4$ & $\max : 18.2$ & $\max : 17.7$ & $\max : 23.6$ & $\max : 84.1$ & \\
\hline $\min : 780$ & $\min : 2.3$ & min: 17.8 & $\min : 15.6$ & min: $\mathbf{1 5 . 5}$ & min: 20.5 & $\min : 67.7$ & \\
\hline \multicolumn{8}{|c|}{ Results Table } \\
\hline \multicolumn{8}{|c|}{ 回詑 $又$ 国 } \\
\hline $\begin{array}{c}\text { Operation } \\
\text { hours after } \\
\text { installation } \\
\text { (hour) }\end{array}$ & $\left|\begin{array}{l}\text { Thermocouple } \\
\text { Assembly }(\Omega)\end{array}\right|$ & $\begin{array}{c}\text { Hydraulic } \\
\text { machinery } \\
\text { control unit } \\
\text { Linear } \\
\text { displacement } \\
\text { sensor }(\Omega)\end{array}$ & $\begin{array}{c}\text { Power } \\
\text { turbine } \\
\text { speed } \\
\text { sensor } \\
(\Omega) \\
\end{array}$ & $\begin{array}{c}\text { Torque } \\
\text { and } \\
\text { overspeed } \\
\text { sensor }(\Omega)\end{array}$ & $\begin{array}{c}\text { Overspeed } \\
\text { leakage } \\
\text { solenoid } \\
\text { valve }(\Omega)\end{array}$ & $\begin{array}{c}\text { Hydraulic } \\
\text { mechanical } \\
\text { control unit } \\
\text { torque } \\
\text { motor }(\Omega) \\
\end{array}$ & $\begin{array}{l}\text { Failure after fault } \\
\text { detection (hour) }\end{array}$ \\
\hline 2000 & 4 & 22 & 18.2 & 17 & 23 & 84 & 195.21318 \\
\hline 2000 & 4 & 22 & 18.1 & 17 & 23 & 84 & 194.335433 \\
\hline 2000 & 4 & 22 & 18 & 17 & 23 & 84 & 193.034542 \\
\hline 2000 & 4 & 22 & 17 & 17 & 23 & 84 & 193.036031 \\
\hline 2000 & 4 & 22 & 16 & 17 & 23 & 84 & 195.203133 \\
\hline
\end{tabular}

Fig. 8. (Color online) Result of model showing the relation between the ohm value of the power turbine speed sensor of the ECU and the predicted time of component failure.

\begin{tabular}{|c|c|c|c|c|c|c|c|}
\hline \multicolumn{8}{|c|}{ Manual Query } \\
\hline \multicolumn{8}{|c|}{ d } \\
\hline $\begin{array}{c}\text { Operation } \\
\text { hours after } \\
\text { installation } \\
\text { (hour) }\end{array}$ & $\begin{array}{l}\text { Thermocouple } \\
\text { Assembly }(\Omega)\end{array}$ & $\begin{array}{l}\text { Hydraulic } \\
\text { machinery } \\
\text { control unit } \\
\text { Linear } \\
\text { displacement } \\
\text { sensor }(\Omega)\end{array}$ & $\begin{array}{c}\text { Power } \\
\text { turbine } \\
\text { speed } \\
\text { sensor } \\
(\Omega) \\
\end{array}$ & $\begin{array}{l}\text { Torque } \\
\text { and } \\
\text { overspeed } \\
\text { sensor }(\Omega)\end{array}$ & $\begin{array}{c}\text { Overspeed } \\
\text { leakage } \\
\text { solenoid } \\
\text { valve }(\Omega)\end{array}$ & $\begin{array}{c}\text { Hydraulic } \\
\text { mechanical } \\
\text { control unit } \\
\text { torque } \\
\text { motor }(\Omega)\end{array}$ & \\
\hline 2000 & 4 & 22 & 18 & 15.5 & 23 & 84 & \\
\hline $\max : 2750$ & $\max : 4.2$ & $\max : 22.4$ & $\max : 18.2$ & $\max : 17.7$ & $\max : 23.6$ & $\max : 84.1$ & \\
\hline $\min : 780$ & $\min : 2.3$ & $\min : 17.8$ & $\min : 15.6$ & $\min : 15.5$ & $\min : 20.5$ & $\min : 67.7$ & \\
\hline \multicolumn{8}{|c|}{ Results Table } \\
\hline \multicolumn{8}{|c|}{ 回缩 $又$ 国 } \\
\hline $\begin{array}{c}\text { Operation } \\
\text { hours after } \\
\text { installation } \\
\text { (hour) }\end{array}$ & $\begin{array}{l}\text { Thermocouple } \\
\text { Assembly }(\Omega)\end{array} \mid$ & $\begin{array}{c}\text { Hydraulic } \\
\text { machinery } \\
\text { control unit } \\
\text { Linear } \\
\text { displacement } \\
\text { sensor }(\Omega)\end{array}$ & $\begin{array}{c}\text { Power } \\
\text { turbine } \\
\text { speed } \\
\text { sensor } \\
(\Omega) \\
\end{array}$ & $\begin{array}{l}\text { Torque } \\
\text { and } \\
\text { overspeed } \\
\text { sensor }(\Omega)\end{array}$ & $\begin{array}{c}\text { Overspeed } \\
\text { leakage } \\
\text { solenoid } \\
\operatorname{valve}(\Omega)\end{array}$ & $\begin{array}{c}\text { Hydraulic } \\
\text { mechanical } \\
\text { control unit } \\
\text { torque } \\
\text { motor }(\Omega)\end{array}$ & \begin{tabular}{|c} 
Failure after fault \\
detection (hour)
\end{tabular} \\
\hline 2000 & 4 & 22 & 18 & 17.6 & 23 & 84 & 193.164924 \\
\hline 2000 & 4 & 22 & 18 & 17.3 & 23 & 84 & 191.206145 \\
\hline 2000 & 4 & 22 & 18 & 17 & 23 & 84 & 193.034542 \\
\hline 2000 & 4 & 22 & 18 & 16 & 23 & 84 & 173.036191 \\
\hline 2000 & 4 & 22 & 18 & 15.5 & 23 & 84 & 167.21866 \\
\hline
\end{tabular}

Fig. 9. (Color online) Result of model showing the relation between the ohm value of the torque and overspeed sensor of the ECU and the predicted time of component failure. 


\begin{tabular}{|c|c|c|c|c|c|c|c|}
\hline \multicolumn{8}{|c|}{ Manual Query } \\
\hline \multicolumn{8}{|c|}{ 陪| } \\
\hline $\begin{array}{c}\text { Operation } \\
\text { hours after } \\
\text { installation } \\
\text { (hour) }\end{array}$ & $\left|\begin{array}{l}\text { Thermocouple } \\
\text { Assembly }(\Omega)\end{array}\right|$ & $\begin{array}{c}\text { Hydraulic } \\
\text { machinery } \\
\text { control unit } \\
\text { Linear } \\
\text { displacement } \\
\text { sensor }(\Omega)\end{array}$ & $\begin{array}{c}\text { Power } \\
\text { turbine } \\
\text { speed } \\
\text { sensor } \\
(\Omega) \\
\end{array}$ & $\begin{array}{l}\text { Torque } \\
\text { and } \\
\text { overspeed } \\
\text { sensor }(\Omega)\end{array}$ & $\begin{array}{l}\text { Overspeed } \\
\text { leakage } \\
\text { solenoid } \\
\text { valve }(\Omega)\end{array}$ & $\begin{array}{c}\text { Hydraulic } \\
\text { mechanical } \\
\text { control unit } \\
\text { torque } \\
\text { motor }(\Omega) \\
\end{array}$ & \\
\hline 2000 & 4 & 22 & 18 & 17 & 21 & 84 & \\
\hline $\max : 2750$ & $\max : 4.2$ & $\max : 22.4$ & $\max : 18.2$ & $\max : 17.7$ & $\max : 23.6$ & $\max : 84.1$ & \\
\hline $\min : 780$ & $\min : 2.3$ & min: 17.8 & min: 15.6 & min: $\mathbf{1 5 . 5}$ & min: 20.5 & $\min : 67.7$ & \\
\hline \multicolumn{8}{|c|}{ Results Table } \\
\hline \multicolumn{8}{|c|}{ 自詑|X 国 } \\
\hline $\begin{array}{c}\text { Operation } \\
\text { hours after } \\
\text { installation } \\
\text { (hour) }\end{array}$ & $\left|\begin{array}{l}\text { Thermocouple } \\
\text { Assembly }(\Omega)\end{array}\right|$ & $\begin{array}{c}\text { Hydraulic } \\
\text { machinery } \\
\text { control unit } \\
\text { Linear } \\
\text { displacement } \\
\text { sensor }(\Omega) \\
\end{array}$ & $\begin{array}{c}\text { Power } \\
\text { turbine } \\
\text { speed } \\
\text { sensor } \\
(\Omega) \\
\end{array}$ & $\begin{array}{c}\text { Torque } \\
\text { and } \\
\text { overspeed } \\
\text { sensor }(\Omega)\end{array}$ & $\begin{array}{c}\text { Overspeed } \\
\text { leakage } \\
\text { solenoid } \\
\text { valve }(\Omega)\end{array}$ & $\begin{array}{c}\text { Hydraulic } \\
\text { mechanical } \\
\text { control unit } \\
\text { torque } \\
\text { motor }(\Omega)\end{array}$ & $\begin{array}{l}\text { Failure after fault } \\
\text { detection (hour) }\end{array}$ \\
\hline 2000 & 4 & 22 & 18 & 17 & 23.6 & 84 & 159.170303 \\
\hline 2000 & 4 & 22 & 18 & 17 & 23.3 & 84 & 182.994085 \\
\hline 2000 & 4 & 22 & 18 & 17 & 23 & 84 & 193.034542 \\
\hline 2000 & 4 & 22 & 18 & 17 & 22 & 84 & 195.61092 \\
\hline 2000 & 4 & 22 & 18 & 17 & 21 & 84 & 177.317705 \\
\hline
\end{tabular}

Fig. 10. (Color online) Result of model showing the relation between the ohm value of the overspeed leakage solenoid valve and the predicted time of component failure.

\begin{tabular}{|c|c|c|c|c|c|c|c|}
\hline \multicolumn{8}{|c|}{ Manual Query } \\
\hline \multicolumn{8}{|c|}{ din $\mid$} \\
\hline $\begin{array}{c}\text { Operation } \\
\text { hours after } \\
\text { installation } \\
\text { (hour) }\end{array}$ & $\left|\begin{array}{l}\text { Thermocouple } \\
\text { Assembly }(\Omega)\end{array}\right|$ & $\begin{array}{c}\text { Hydraulic } \\
\text { machinery } \\
\text { control unit } \\
\text { Linear } \\
\text { displacement } \\
\text { sensor }(\Omega) \\
\end{array}$ & $\begin{array}{c}\text { Power } \\
\text { turbine } \\
\text { speed } \\
\text { sensor } \\
(\Omega) \\
\end{array}$ & $\begin{array}{l}\text { Torque } \\
\text { and } \\
\text { overspeed } \\
\text { sensor }(\Omega)\end{array}$ & $\begin{array}{l}\text { Overspeed } \\
\text { leakage } \\
\text { solenoid } \\
\text { valve }(\Omega)\end{array}$ & $\begin{array}{c}\text { Hydraulic } \\
\text { mechanical } \\
\text { control unit } \\
\text { torque } \\
\text { motor }(\Omega) \\
\end{array}$ & \\
\hline 2000 & 4 & 22 & 18 & 17 & 23 & 70 & \\
\hline $\max : 2750$ & $\max : 4.2$ & $\max : 22.4$ & $\max : 18.2$ & $\max : 17.7$ & $\max : 23.6$ & $\max : 84.1$ & \\
\hline min: 780 & $\min : 2.3$ & $\min : 17.8$ & $\min : 15.6$ & $\min : 15.5$ & $\min : 20.5$ & $\min : 67.7$ & \\
\hline \multicolumn{8}{|c|}{ Results Table } \\
\hline \multicolumn{8}{|c|}{ 四绾|X 国 } \\
\hline $\begin{array}{c}\text { Operation } \\
\text { hours after } \\
\text { installation } \\
\text { (hour) }\end{array}$ & $\begin{array}{l}\text { Thermocouple } \\
\text { Assembly }(\Omega)\end{array}$ & $\begin{array}{c}\text { Hydraulic } \\
\text { machinery } \\
\text { control unit } \\
\text { Linear } \\
\text { displacement } \\
\text { sensor }(\Omega) \\
\end{array}$ & $\begin{array}{c}\text { Power } \\
\text { turbine } \\
\text { speed } \\
\text { sensor } \\
(\Omega) \\
\end{array}$ & $\begin{array}{l}\text { Torque } \\
\text { and } \\
\text { overspeed } \\
\text { sensor }(\Omega)\end{array}$ & $\begin{array}{l}\text { Overspeed } \\
\text { leakage } \\
\text { solenoid } \\
\text { valve }(\Omega)\end{array}$ & $\begin{array}{c}\text { Hydraulic } \\
\text { mechanical } \\
\text { control unit } \\
\text { torque } \\
\text { motor }(\Omega)\end{array}$ & $\begin{array}{l}\text { Failure after fault } \\
\text { detection (hour) }\end{array}$ \\
\hline 2000 & 4 & 22 & 18 & 17 & 23 & 84.1 & 192.891605 \\
\hline 2000 & 4 & 22 & 18 & 17 & 23 & 84 & 193.034542 \\
\hline 2000 & 4 & 22 & 18 & 17 & 23 & 80 & 194.223834 \\
\hline 2000 & 4 & 22 & 18 & 17 & 23 & 75 & 178.676381 \\
\hline 2000 & 4 & 22 & 18 & 17 & 23 & 70 & 137.6394 \\
\hline
\end{tabular}

Fig. 11. (Color online) Result of model showing the relation between the ohm value of the torque motor of the hydraulic machinery control unit and the predicted time of component failure.

(7) The ohm values of the torque motor of the hydraulic machinery control unit were input as $84.1,84,80,75$, and $70 \Omega$ with the other factors constant. The predicted times were 192, 193, 194, 178, and $137 \mathrm{~h}$, respectively, which shows that ohm value of the torque motor of the hydraulic machinery control unit did not affect the prediction (Fig. 11).

\section{Conclusions}

A new model that uses the modified Delphi method and BPNN to predict the time of component failure in the ECU of a T700 engine was proposed. The predicted values were 
verified using the results of statistical analysis such as the expert consistency index and MAPE. Seventeen factors were chosen after the questionnaire survey, then through a second survey with 12 experts of various experience, the following seven important factors were chosen for the model: operation hours after installation, times of thermocouple assembly, and the ohm values of the linear displacement sensor of the hydraulic pressure control unit, power turbine speed sensor, torque and overspeed sensor, overspeed leakage solenoid valve, and the torque motor of the hydraulic control unit. Fifteen sets of the real maintenance data obtained during 2011-2013 were used to train the model using Alyuda NeuroIntelligence software through the comparison of the predicted and real times. In the case of 12 neurons in the hidden layer, a learning rate of 0.2 , and 2000 epochs, the prediction result showed correlation and matching rates of 0.999 and 0.997 , respectively. The prediction accuracy calculated from MAPE analysis was 92.45\%. The lowest accuracy was $90.53 \%$ for one data set. Assuming that the ECU of a T700 has been operating for $2000 \mathrm{~h}$ after installation, the longest interval before failure was predicted to be around $193 \mathrm{~h}$. On average, the predicted operating time until failure was between 174 and $178 \mathrm{~h}$, corresponding to total operating times of 2174 to $2178 \mathrm{~h}$ until failure. Therefore, the results indicate that the ECU of a T700 should be maintained after $2100 \mathrm{~h}$ of operation. Inspection of the components also needs to be performed after every $100 \mathrm{~h}$ of flight, while the engine should be inspected after every $50 \mathrm{~h}$ of flight. Appropriate maintenance of the ECU will prevent unexpected failures and accidents.

The results of this research provide the manufacturer with basic information for improving the quality of the ECU, which will increase its reliability and flight safety. This research is expected to lead to related future studies on a preventive maintenance and management strategy for aircraft components. The balance between cost and time saving and efficiency also needs to be investigated. The BPNN model in this study will be improved in the future by employing sufficient training data to obtain higher accuracy.

\section{References}

1 M. Foust, D. Thomsen, R. Stickles, C. Cooper, and W. Dodds: Proc. 2012 50th AIAA Aerospace Sciences Meeting including the New Horizons Forum and Aerospace Exposition (AIAA, 2012) 1-12. https://doi. org/10.2514/6.2012-936

2 S. Kelly and T. Stanley: Mind Soc. 2 (2012) 335. https://doi.org/10.4236/sm.2012.24044

3 H. Zou, X. Gong, S. Wang, and W. Chen: Int. J. Clin. Med. 11 (2020) 242. https://doi.org/10.4236/ ijcm.2020.115025

4 J.-W. Murry and J.-O. Hammons: Rev. Higher Educ. 18 (1995) 423. https://doi.org/10.1353/rhe.1995.0008

5 B. Mashood and G. Millbank: J. Behav. Brian Sci. 6 (2016) 219. https://doi.org/10.4236/jbbs.2016.65022.

6 S. O. T. Ogaji and R. Singh: Appl. Soft. Comput. 3 (2003) 259. https://doi.org/10.1016/S1568-4946(03)00038-3

7 P.-C. Chang, C.-H. Liu, J.-L. Lin, C.-Y. Fan, and C. S. P. Ng: Exp. Syst. Appl. 36 (2009) 6889. https://doi. org/10.1016/j.eswa.2008.08.077

8 T. Chen: Appl. Soft. Comput. 2 (2003) 211. https://doi.org/10.1016/S1568-4946(02)00066-2

9 F.-L. Chen, Y.-C. Chen, and J.-Y. Kuo: Exp. Syst. Appl. 37 (2010) 4358. https://doi.org/10.1016/j. eswa.2009.11.092

10 K. Dehghani and A. Nekahi: Mater. Des. 31 (2010). https://doi.org/10.1016/j.matdes.2009.10.020

11 W. Yuan and Y. Zeng: Creat. Educ. 8 (2017) 305. https://doi.org/10.4236/ce.2017.83024

12 G. Li, S. Kumar. S. Hari, M. Sullivan, T. Tsai, K. Pattabiraman, J. Emer, and S. W. Keckler: Proc. 2017 Int. Conf. High Performance Computing, Networking, Storage and Analysis (ACM, 2017) 1-12. https://doi. org/10.1145/3126908.3126964

13 S. Jawahar and P. Ramamoorthy: Circuits Syst. 7 (2016) 3371. https://doi.org/10.4236/cs.2016.710287 
14 S. Zhang: JSSM 12 (2019) 126. https://doi.org/10.4236/jssm.2019.122008

15 S. H. Ling: JILSA 2 (2010) 1. https://doi.org/10.4236/jilsa.2010.21001

16 M. Maqableh, H. Karajeh, and R. Masa'deh: Comm. Netw. 6 (2014) 191. https://doi.org/10.4236/cn.2014.63021

17 A. Yayík and Y. Kutlu: Neural Netw. World 2 (2014) 177. https://doi.org/10.14311/nnw.2014.24.011

\section{Appendix I}

Data sets of parameters for selected factors of 50 ECUs.

\begin{tabular}{|c|c|c|c|c|c|c|c|c|}
\hline \multirow[b]{2}{*}{ Group } & \multicolumn{7}{|c|}{ Input layer } & \multirow{2}{*}{$\begin{array}{c}\begin{array}{c}\text { Output } \\
\text { layer }\end{array} \\
\begin{array}{c}\text { Time of } \\
\text { failure } \\
\text { after }\end{array} \\
\text { detection } \\
\text { (h) }\end{array}$} \\
\hline & $\begin{array}{l}\text { Opera- } \\
\text { tion hours } \\
\text { after } \\
\text { install- } \\
\text { ation }\end{array}$ & $\begin{array}{l}\text { Resistance } \\
\text { of thermo- } \\
\text { couple } \\
\text { assembly } \\
(\Omega)\end{array}$ & $\begin{array}{l}\text { Hydraulic } \\
\text { machinery } \\
\text { control } \\
\text { unit linear } \\
\text { displacement } \\
\text { sensor }(\Omega)\end{array}$ & $\begin{array}{l}\text { Power } \\
\text { turbine } \\
\text { speed } \\
\text { sensor }(\Omega)\end{array}$ & $\begin{array}{l}\text { Torque and } \\
\text { overspeed } \\
\text { sensor }(\Omega)\end{array}$ & $\begin{array}{l}\text { Overspeed } \\
\text { leakage } \\
\text { solenoid } \\
\text { valve }(\Omega)\end{array}$ & $\begin{array}{c}\text { Torque } \\
\text { motor of } \\
\text { hydraulic } \\
\text { machinery } \\
\text { control unit } \\
(\Omega)\end{array}$ & \\
\hline 1 & 1420 & 2.8 & 22.4 & 16.2 & 16.5 & 22.1 & 71.6 & 189 \\
\hline 2 & 2750 & 2.6 & 21.3 & 16.6 & 16.8 & 21.7 & 70.5 & 123 \\
\hline 3 & 1400 & 2.3 & 21.5 & 16.2 & 17.1 & 20.5 & 71.5 & 161 \\
\hline 4 & 165 & 3.7 & 20.5 & 18.1 & 18.0 & 22.5 & 76.4 & 95 \\
\hline 5 & 1480 & 2.9 & 19.0 & 17.0 & 16.7 & 22.4 & 76.8 & 104 \\
\hline 6 & 1630 & 2.8 & 18.8 & 16.3 & 16.8 & 22.7 & 77.1 & 125 \\
\hline 7 & 2450 & 3.6 & 19.0 & 17.3 & 17.2 & 22.7 & 73.4 & 167 \\
\hline 8 & 2380 & 4.0 & 20.3 & 17.6 & 17.2 & 22.6 & 76.3 & 198 \\
\hline 9 & 1740 & 2.7 & 21.6 & 16.4 & 16.0 & 21.3 & 71.2 & 141 \\
\hline 10 & 1720 & 2.8 & 21.7 & 16.8 & 16.3 & 22.4 & 72.2 & 178 \\
\hline 11 & 1750 & 2.7 & 19.0 & 16.4 & 16.5 & 22.4 & 74.3 & 115 \\
\hline 12 & 1700 & 2.7 & 20.4 & 17.0 & 17.2 & 22.3 & 84.1 & 110 \\
\hline 13 & 2140 & 3.0 & 19.6 & 17.4 & 16.7 & 22.4 & 79.0 & 193 \\
\hline 14 & 2430 & 4.6 & 22.0 & 18.1 & 17.6 & 23.6 & 76.9 & 176 \\
\hline 15 & 2260 & 3.3 & 20.1 & 17.0 & 16.8 & 22.8 & 76.7 & 148 \\
\hline 16 & 2260 & 3.8 & 19.5 & 16.6 & 16.7 & 21.9 & 76.6 & 193 \\
\hline 17 & 2120 & 2.5 & 19.1 & 15.7 & 15.6 & 20.9 & 70.2 & 188 \\
\hline 18 & 1960 & 2.6 & 20.9 & 15.7 & 15.5 & 21.3 & 68.1 & 179 \\
\hline 19 & 2280 & 2.8 & 17.8 & 15.6 & 16.1 & 21.6 & 73.6 & 107 \\
\hline 20 & 2060 & 2.8 & 20.3 & 17.3 & 16.8 & 22.6 & 73.4 & 118 \\
\hline 21 & 780 & 2.8 & 21.7 & 16.9 & 17.2 & 22.1 & 74.0 & 190 \\
\hline 22 & 1670 & 2.8 & 18.6 & 15.9 & 15.8 & 21.5 & 73.1 & 85 \\
\hline 23 & 1780 & 2.9 & 17.9 & 16.0 & 15.9 & 21.4 & 71.2 & 167 \\
\hline 24 & 1470 & 2.9 & 20.6 & 16.5 & 16.1 & 21.0 & 71.5 & 123 \\
\hline 25 & 2150 & 3.2 & 18.6 & 16.2 & 16.3 & 21.5 & 74.4 & 174 \\
\hline 26 & 1720 & 2.7 & 18.4 & 16.1 & 15.8 & 21.1 & 71.5 & 180 \\
\hline 27 & 1800 & 2.9 & 20.7 & 15.9 & 16.6 & 21.4 & 68.1 & 135 \\
\hline 28 & 1950 & 3.8 & 19.6 & 16.4 & 16.7 & 22.3 & 69.8 & 104 \\
\hline 29 & 2160 & 3.5 & 21.5 & 16.2 & 15.8 & 21.5 & 68.8 & 96 \\
\hline 30 & 2050 & 3.2 & 19.9 & 16.5 & 16.6 & 22.5 & 71.9 & 117 \\
\hline 31 & 950 & 2.8 & 22.2 & 16.4 & 15.9 & 22.3 & 76.1 & 178 \\
\hline 32 & 1250 & 2.7 & 17.8 & 17.5 & 17.5 & 22.4 & 74.0 & 183 \\
\hline 33 & 1370 & 3.1 & 18.7 & 17.5 & 16.5 & 22.6 & 73.3 & 179 \\
\hline 34 & 1280 & 2.8 & 21.4 & 16.1 & 15.6 & 21.0 & 67.7 & 148 \\
\hline 35 & 2200 & 3.0 & 18.4 & 15.9 & 15.8 & 21.2 & 69.7 & 101 \\
\hline 36 & 2140 & 3.0 & 22.2 & 16.5 & 16.9 & 22.8 & 73.7 & 154 \\
\hline 37 & 1860 & 3.0 & 18.7 & 17.0 & 16.7 & 22.3 & 76.8 & 166 \\
\hline
\end{tabular}




\begin{tabular}{|c|c|c|c|c|c|c|c|c|}
\hline \multirow[b]{2}{*}{ Group } & \multicolumn{7}{|c|}{ Input layer } & \multirow{2}{*}{$\begin{array}{c}\begin{array}{c}\text { Output } \\
\text { layer }\end{array} \\
\text { Time of } \\
\text { failure } \\
\text { after } \\
\text { detection } \\
\text { (h) }\end{array}$} \\
\hline & $\begin{array}{l}\text { Opera- } \\
\text { tion hours } \\
\text { after } \\
\text { install- } \\
\text { ation }\end{array}$ & $\begin{array}{l}\text { Resistance } \\
\text { of thermo- } \\
\text { couple } \\
\text { assembly } \\
(\Omega)\end{array}$ & $\begin{array}{l}\text { Hydraulic } \\
\text { machinery } \\
\text { control } \\
\text { unit linear } \\
\text { displacement } \\
\text { sensor }(\Omega)\end{array}$ & $\begin{array}{c}\text { Power } \\
\text { turbine } \\
\text { speed } \\
\text { sensor }(\Omega)\end{array}$ & $\begin{array}{l}\text { Torque and } \\
\text { overspeed } \\
\text { sensor }(\Omega)\end{array}$ & $\begin{array}{l}\text { Overspeed } \\
\text { leakage } \\
\text { solenoid } \\
\text { valve }(\Omega)\end{array}$ & $\begin{array}{c}\text { Torque } \\
\text { motor of } \\
\text { hydraulic } \\
\text { machinery } \\
\text { control unit } \\
(\Omega)\end{array}$ & \\
\hline 38 & 1940 & 3.1 & 19.0 & 17.0 & 17.1 & 22.9 & 78.0 & 173 \\
\hline 39 & 1580 & 3.1 & 20.2 & 17.4 & 17.0 & 22.7 & 75.7 & 148 \\
\hline 40 & 1730 & 2.7 & 19.0 & 16.7 & 16.6 & 21.9 & 73.9 & 142 \\
\hline 41 & 890 & 2.5 & 22.2 & 16.9 & 16.4 & 22.7 & 70.8 & 195 \\
\hline 42 & 1960 & 3.1 & 19.7 & 16.5 & 17.5 & 22.5 & 75.1 & 148 \\
\hline 43 & 1570 & 2.9 & 19.7 & 17.3 & 16.8 & 23.2 & 75.8 & 182 \\
\hline 44 & 1780 & 2.8 & 19.2 & 16.5 & 16.5 & 22.1 & 74.4 & 179 \\
\hline 45 & 1670 & 2.8 & 21.8 & 17.3 & 17.7 & 22.1 & 73.2 & 120 \\
\hline 46 & 2020 & 3.0 & 19.6 & 18.2 & 16.9 & 23.1 & 78.8 & 106 \\
\hline 47 & 2060 & 3.2 & 20.0 & 16.9 & 16.8 & 22.7 & 75.8 & 102 \\
\hline 48 & 1870 & 2.7 & 21.3 & 16.0 & 16.2 & 22.4 & 74.2 & 158 \\
\hline 49 & 1730 & 2.8 & 21.5 & 16.5 & 17.4 & 21.9 & 73.1 & 149 \\
\hline 50 & 1960 & 3.8 & 19.0 & 16.0 & 17.2 & 21.3 & 69.8 & 173 \\
\hline 51 & 2280 & 3.5 & 20.2 & 16.5 & 16.0 & 21.6 & 68.8 & 148 \\
\hline 52 & 2260 & 2.7 & 22.2 & 18.2 & 16.8 & 21.9 & 71.5 & 154 \\
\hline 53 & 2060 & 3.2 & 19.0 & 17.7 & 16.3 & 22.6 & 71.9 & 142 \\
\hline 54 & 780 & 2.8 & 22.2 & 16.9 & 16.5 & 22.1 & 76.1 & 195 \\
\hline 55 & 1630 & 2.8 & 19.0 & 16.9 & 15.9 & 22.7 & 77.1 & 193 \\
\hline 56 & 1740 & 3.7 & 22.0 & 16.5 & 15.6 & 22.1 & 71.2 & 107 \\
\hline 57 & 1670 & 2.7 & 19.7 & 15.9 & 17.2 & 21.5 & 74.0 & 148 \\
\hline 58 & 2140 & 4.0 & 20.9 & 16.4 & 17.1 & 22.4 & 79.0 & 167 \\
\hline 59 & 2260 & 4.2 & 20.0 & 17.7 & 17.4 & 23.6 & 74.6 & 107 \\
\hline 60 & 1780 & 3.1 & 19.7 & 16.0 & 16.7 & 21.4 & 73.3 & 182 \\
\hline 61 & 1470 & 2.8 & 19.2 & 16.5 & 17.6 & 21.0 & 67.7 & 179 \\
\hline 62 & 2150 & 3.0 & 21.8 & 16.2 & 16.8 & 21.5 & 69.7 & 120 \\
\hline 63 & 2140 & 2.7 & 22.2 & 18.2 & 16.9 & 22.1 & 74.3 & 190 \\
\hline 64 & 1860 & 2.9 & 18.7 & 16.9 & 16.7 & 21.7 & 84.1 & 85 \\
\hline 65 & 1940 & 3.8 & 19.0 & 16.0 & 17.1 & 20.5 & 79.0 & 167 \\
\hline 66 & 1750 & 2.8 & 19.5 & 16.1 & 16.9 & 23.1 & 74.3 & 190 \\
\hline 67 & 1580 & 3.5 & 20.2 & 16.5 & 17.0 & 22.5 & 76.9 & 123 \\
\hline 68 & 2260 & 2.8 & 20.3 & 16.5 & 16.6 & 23.6 & 76.7 & 174 \\
\hline 69 & 1720 & 2.9 & 20.1 & 16.2 & 15.8 & 22.1 & 72.2 & 118 \\
\hline 70 & 1730 & 3.2 & 19.0 & 17.7 & 16.6 & 22.4 & 76.7 & 174 \\
\hline 71 & 890 & 2.8 & 22.2 & 16.9 & 16.8 & 22.7 & 76.6 & 180 \\
\hline 72 & 2430 & 2.7 & 17.8 & 16.2 & 17.0 & 21.9 & 76.9 & 123 \\
\hline 73 & 1960 & 2.7 & 19.7 & 15.9 & 17.2 & 22.7 & 70.2 & 135 \\
\hline 74 & 2450 & 2.6 & 20.4 & 15.9 & 17.5 & 22.5 & 73.4 & 188 \\
\hline 75 & 1700 & 3.6 & 19.1 & 15.9 & 16.7 & 22.7 & 84.1 & 85 \\
\hline 76 & 2120 & 2.9 & 18.7 & 16.9 & 17.2 & 20.9 & 68.1 & 166 \\
\hline 77 & 1570 & 3.1 & 19.7 & 16.0 & 17.2 & 22.6 & 68.1 & 104 \\
\hline 78 & 1780 & 2.8 & 19.2 & 16.5 & 16.0 & 21.3 & 73.6 & 96 \\
\hline 79 & 2380 & 2.3 & 19.6 & 16.0 & 16.5 & 23.2 & 76.3 & 179 \\
\hline 80 & 1670 & 3.0 & 21.8 & 16.2 & 16.3 & 22.4 & 73.4 & 117 \\
\hline
\end{tabular}

